\title{
FORMAÇÃO INICIAL DO PROFESSOR DE LÍNGUA INGLESA A PARTIR DA ABORDAGEM DO LETRAMENTO CIENTÍFICO
}

\section{PRE-SERVICE ENGLISH LANGUAGE TEACHER BASED ON THE SCIENTIFIC LITERACY}

Lívia Chaves de Melo'

\begin{abstract}
Resumo: Situada na perspectiva interdisciplinar da Linguística Aplicada, esta pesquisa foi desenvolvida com o propósito de elaborar contribuiçôes para a conduçăo do trabalho de supervisâo do estágio obrigatório em ensino de Língua Inglesa a partir dos estudos do letramento científico. A perspectiva dialógica bakhtiniana e os estudos do letramento científico foram utilizados como principais aportes teóricos. A abordagem da pesquisa qualitativa e a metodologia da análise documental foram assumidas para caracterizar o tratamento dado aos relatórios de estágio, documentos pesquisados. Os resultados da investigaçâo mostraram que a escrita dos relatórios de estágio sâo respostas às orientaçôes dadas na disciplina, e a atividade de observaçấo de aulas pode adquirir novos sentidos, os quais săo apontados neste artigo.
\end{abstract}

Palavras-chave: Gênero discursivo. Formaçāo de professores. Estágio supervisionado de inglês. Ensino de língua.

Abstract: Within the interdisciplinary field of Applied Linguistics, this research proposes elaborating contributions to the conduction in the compulsory Supervised Internship in English Language Teaching from Scientific Literary studies. Dialogical studies of language according to Bakhtin's perspective and Scientific Literacy are the theoretical apparatuses that guided this research. Qualitative research approach and the methodology of documentation was applied to characterize supervised internship reports, the dataset investigated. The research results show that the writing of the supervised internship reports is answers given in the subject on the observation lessons. This activity can acquire new meanings, which are suggested in this research.

Keywords: Speech Genres. Teacher's development. English teaching practicum. Language teaching.

1 Doutora em Letras: Ensino de Língua e Literatura. Professora do Magistério Superior na Universidade Federal do Tocantins (UFT), Câmpus Universitário de Porto Nacional. E-mail: liviamelo@uft.edu.br 


\title{
INTRODUÇÃO
}

\begin{abstract}
"Năo há ensino sem pesquisa e pesquisa sem ensino [...]. Enquanto ensino continuo buscando, reprocurando. Ensino porque busco, porque indaguei, porque indago e me indago. Pesquiso para constatar, constatando, intervenho, intervindo educo e me educo. Pesquiso para conhecer o que ainda năo conheço e comunicar ou anunciar a novidade" (FREIRE, 1999, p. 32).
\end{abstract}

Esta pesquisa está situada no campo interdisciplinar da Linguística Aplicada, área do conhecimento articuladora de múltiplos domínios do conhecimento, que tem preocupaçấo com a linguagem nos mais variados contextos sociais (cf. CELANI, 2008) e que vê a formaçáo docente como um campo de atuaçăo. Investigamos a escrita de Relatórios de Estágio Supervisionado (doravante RES), produzidos por professores em formaçâo inicial no contexto de instruçăo formal da disciplina Prática de Ensino e Estágio Supervisionado em Língua Inglesa e Literaturas I, ofertada na licenciatura em Letras: habilitaçâo em Língua Inglesa e respectivas literaturas, na Universidade Federal do Tocantins (UFT), Câmpus Universitário de Porto Nacional.

O propósito desta investigaçăo é elaborar contribuiçōes para a conduçāo do trabalho de supervisâo do estágio obrigatório em ensino de Língua Inglesa a partir dos estudos do letramento científico, ainda incipientes no campo de estudos da linguagem, conforme destacado por Silva (2016).

O estágio supervisionado obrigatório é compreendido como atividade de desenvolvimento de habilidades e competências necessárias para o exercício da profissăo do magistério (cf. PIMENTA; LIMA, 2004). Propicia a troca de experiências ou saberes entre os professores em formaçáo inicial, sob a supervisăo de professores-orientadores vinculados à universidade, e os professores em serviço. Proporciona o contato mais direto com a parte prática do currículo, capacitando os futuros profissionais para atuarem em sala de aula de forma mais crítica, dinâmica e motivadora.

Usamos as denominaçôes aluno-mestre e suas flexôes gramaticais para nos referirmos aos discentes regularmente matriculados na disciplina Prática de Ensino e Estágio Supervisionado em Língua Inglesa e Literaturas I da licenciatura em Letras focalizada. Empregamos também professora-orientadora para fazermos referência ao profissional docente, responsável pela disciplina de estágio no contexto universitário e professor-colaborador ao profissional em exercício da profissāo, responsável pela disciplina na escola de educaçáo básica, onde a prática de estágio supervisionado é desenvolvida.

Este artigo está organizado em três principais seçōes, além desta Introduçâo, das Consideraçôes finais e Referências. Na seçâo denominada Caracterizaçâo do estágio obrigatório, caracterizamos o estágio supervisionado em língua inglesa na licenciatura em Letras focalizada. A seçâo Algumas bases teóricas concerne aos aportes teóricos utilizados, a saber a perspectiva dialógica bakhtiniana e os estudos do letramento científico. A seçāo Análise dos dados é destinada às análises textuais dos dados de pesquisa.

\section{Caracterizaçăo do estágio obrigatório:}

No contexto investigado, as atividades do estágio supervisionado em língua inglesa iniciam-se na licenciatura em Letras, na segunda metade do curso, ou seja, no $5^{\circ}$ período. Os alunos-mestre devem cursar quatro disciplinas, Estágios I, II, III e IV, com uma 
carga horário de 105 horas para cada componente curricular, totalizando 420 horas de duraçấo dos estágios obrigatórios.

Tais disciplinas acontecem em dois momentos, constituídos por aulas teóricas no contexto da universidade, as quais propiciam discussôes sobre a dinâmica da aula de língua inglesa no ensino básico e práticas nas escolas-campo de ensino básico. As aulas práticas săo desenvolvidas preferencialmente nas instituiçōes públicas, localizadas no município de Porto Nacional. Os alunos-mestre săo os responsáveis por selecionar as escolas-campo para a realizaçâo do estágio com vagas disponíveis para a implementaçâo das açôes exigidas pela disciplina. Nâo há instituiçôes de ensino com convênios diretos entre universidade-escola na licenciatura investigada.

O desenvolvimento das atividades práticas estâo divididas em observaçâo e regência. Na primeira, os alunos-mestre observam aulas de língua inglesa ministradas por um professor-colaborador em exercício da profissăo e refletem criticamente sobre as aulas observadas. Na segunda, esses mesmos alunos-mestre săo responsáveis por ministrar, sob a supervisâo do professor-colaborador e da professora-orientadora, algumas aulas, tentando articular a teoria estudada na academia e a prática vivenciada no ambiente real de ensino-aprendizagem.

No Estágio I, mais especificamente, os alunos-mestre observam e participam das atividades escolares tanto no Ensino Fundamental II como no Ensino Médio, reconhecem a totalidade do espaço escolar, examinam o Projeto Político Pedagógico da escola-campo, auxiliam o professor-colaborador, entrevistam professores, alunos e gestores. A carga horária desta disciplina é distribuída em 75 (setenta e cinco) horas teóricas e 30 (trinta) horas de estágio na escola-campo (PPC², 2009, p. 111). Nesta disciplina, os estagiários nâo ministram aulas.

No contexto investigado, no Estágio I, năo é obrigatório a observaçăo de aulas. No entanto, solicitamos aos acadêmicos que observassem no mínimo cinco aulas para que tivessem um contato mais direto com o espaço da sala de aula. Nas três disciplinas subsequentes, as observaçōes săo obrigatórias e seguidas pelas regências nas escolas-campo.

Ao final dos estágios, os alunos-mestre produzem RES como trabalho escrito final das disciplinas para apresentar as suas reflexóes sobre as experiências vivenciadas como professor em formaçăo inicial durantes as atividades de observaçăo, planejamento e regência nas escolas-campo. Esse documento de caráter mais narrativo e subjetivo é o principal instrumento avaliador da disciplina. Nele, os estagiários costumam destacar os acontecimentos que mais lhes chamaram a atençăo durante a prática pedagógica. Além dos RES, outras atividades săo desenvolvidas nos estágios, tais como a escrita de resenhas críticas, resumos, elaboraçăo de planejamentos de aulas, seminários temáticos e a produçâo de materiais didáticos para o ensino de língua inglesa, atendendo aos interesses e necessidades dos alunos da Educaçăo Básica.

\section{Algumas bases teóricas:}

A Torre de Babel, uma das histórias bíblicas mais conhecidas da humanidade, pertencente ao livro de Gênesis, conta que toda a terra possuía uma mesma língua.

2 Projeto Pedagógico do curso de licenciatura em Letras: habilitaçăo em Língua Inglesa e respectivas literaturas (PPC, Letras/Porto Nacional). Porto Nacional, 2009. 
Os descendentes de Noé, interessados na eternidade, edificaram uma torre para tocar os céus. Deus, frustrou o propósito deles, multiplicando as línguas de tal maneira que nâo podiam comunicar entre si e isso deu origem à multiplicaçăo de línguas e a divisâo entre os povos. No referido livro, temos ainda outra narrativa que envolve o uso de uma variedade de línguas. Em Atos dos Apóstolos, é dito que, no dia de pentecostes, uma festa judaica realizada para comemorar o início das colheitas, o povo recebeu a manifestaçăo do Espírito Santo que desceu do céu em forma de línguas de fogo e começaram a falar em outras línguas. Ao contrário do castigo vivido na Babel, as línguas de fogo săo apresentadas como o caráter ecumênico da festa que reuniu pessoas de todas as raças e diferentes condiçóes sociais. É o encontro da diversidade e o entendimento das diferenças (cf. MATEUS, 2009).

Trazendo as duas imagens bíblicas para o contexto da formaçăo de professores, a confusâo das línguas em Babel, que significa conflito, castigo, incapacidade de compreensâo mútua, representa as tensóes existentes entre a teoria e a prática que agrava o distanciamento entre universidade e escola, pois imagina-se que, na universidade, se faz ciência e, se produz conhecimento, enquanto que, na escola educa-se os alunos. Por outro lado, podemos compreender as línguas de fogo como um esforço de ressignificar teoria e prática para aproximar essas duas instituiçōes de ensino.

É neste cenário que encontramos a responsabilidade que as disciplinas de Estágio Supervisionado têm recebido nas licenciaturas: o momento por excelência de ligaçáo entre as teorias acadêmicas com as demandas do ensino no local de trabalho, náo eximindo tal demanda das demais disciplinas, consideradas como teóricas. Idealizase que, nos estágios, haja um esforço em unir as habilidades de pesquisar com as de educar, ou seja, educar através da pesquisa (cf. DEMO, 2010).

Nos estágios obrigatórios, no contexto focalizado, conforme acentuamos, uma das formas de avaliaçâo é a escrita de RES pelos alunos-mestre, referente às vivências em campo e formas de significaçăo. A partir da abordagem dialógica da linguagem, fundamentada no conjunto das obras de Bakhtin (2000; 2002; 2013), compreendemos os RES como gênero discursivo. Nesta escrita, os alunos-mestre dialogam com os autores lidos que fazem parte da bibliografia da disciplina, e, até mesmo, de outros componentes curriculares, ou contextos sociais diversos, para servir de base para produzir os seus argumentos. Esse diálogo é uma prática letrada acadêmica.

Para Bakhtin (2000; 2002; 2013), os gêneros discursivos săo formas padrăo, relativamente estáveis de enunciados, construídos sócio-historicamente. Constituídos de construçăo composicional (organizaçâo do gênero), conteúdo temático (assunto) e estilo verbal (linguagem típica de cada gênero e subjetividade do escrevente), os gêneros săo socialmente situados em determinadas circunstâncias temporais, espaciais, ideológicas e săo imprescindíveis para a interaçăo comunicativa na sociedade. Para o teórico, gênero discursivo náo se limita a textos ou estruturas e formas linguísticas por elas mesmas, embora os considere, implica dialogismo (cf. BRAIT; PISTORI, 2012).

Com base nos estudos bakhtinianos, depreendemos que os gêneros que circulam na esfera acadêmica săo mais padronizados e sofrem poucas reformulaçôes. No entanto, o relatório de estágio é um gênero discursivo que apesar de ser elaborado na situaçăo formal da academia, é mais maleável, flexível e criativo, pois manifesta-se em uma escrita mais pessoal, subjetiva, dinâmica com maior liberdade de reformulaçăo. 
Essa escrita refere-se a formas particulares de se produzir conhecimento, ler e escrever que singularizam nos gêneros institucionais que circulam na universidade, podendo funcionar como instrumento mediador para o letramento científico na formaçăo docente.

Existem diversas compreensôes teóricas sobre letramento científico, assim como há inúmeras conceituaçôes sobre o letramento. No campo do Ensino de Ciências Naturais, letramento científico tem sido usado há mais de quadro décadas e significa preparar os alunos para atuarem no mundo atual ao serem defrontados com problemas autênticos. É fornecer um ensino nâo somente de noçôes e conceitos científicos, mas um ensino que prepare os alunos para 'fazer ciência', buscar resolver problemas e explicá-los aos demais (cf. SASSERON; CARVALHO, 2008).

Como já tivemos oportunidade de comentar em outro trabalho (MELO, 2017), no âmbito da Linguística Aplicada, compreendemos este fenômeno como conhecimentos e habilidades de leitura e escrita envolvidas na produçăo do conhecimento de domínio científico que permite a participaçăo ativa dos estudantes na sociedade. Em complemento a essa conceituaçăo, Silva (2016, p. 14), na Linguística Aplicada e numa perspectiva crítica, acentua que o letramento científico envolve "práticas investigativas informadas pela escrita em funçâo da produçâo de conhecimentos necessários ao desenvolvimento humano na complexidade que lhe é constitutiva em diferentes domínios sociais, a exemplo das práticas de formaçăo de professores".

Nessa perspectiva, ensinar năo é simplesmente transferir, depositar, oferecer conhecimento, mais que isso, é criar possibilidades para a produçăo e a (re)construçăo de saberes. É contribuir para a formaçáo de sujeitos autônomos, livres, criativos, protagonistas de sua aprendizagem (FREIRE, 1999).

\section{ANÁLISE DOS DADOS}

Esta investigaçăo se caracteriza como uma pesquisa documental de natureza qualitativa. Compreendemos documentos como enunciados responsáveis por registrar informaçôes/conhecimentos específicos em sistemas específicos. Tudo o que é vestígio do passado, tudo o que serve de testemunho é considerado como documento ou 'fonte' de investigaçăo (SÁ-SILVA; ALMEIDA; GUINDANI, 2009).

O corpus da pesquisa é constituído pela versăo final de três RES elaborados na disciplina Prática de Ensino e Estágio Supervisionado em Língua Inglesa e Literaturas I, por nós ministrada no segundo semestre letivo do ano de 2016. Antes da entrega da versâo final dos documentos, os acadêmicos enviaram, por e-mail, a redaçăo da primeira e segunda versăo. O retorno a escrita dos textos também se deu por e-mail, porém, nem todos os comandos orientadores de reescrita foram atendidos pelos alunos-mestre. Os RES investigados estâo disponíveis em documentos impressos e também digitalizados em Compact Disc Read-Only Memory (CD ROM).

Os excertos selecionados para investigaçăo foram transcritos ipsis litteris e as identificaçôes dos autores suprimidas. Usamos apenas as seguintes informaçôes para identificarmos os excertos: aluno-mestre, disciplina, ano letivo de produçăo, semestre letivo e a seçăo do relatório de onde foram retirados. Analisamos os dados de pesquisa a partir de marcas gramaticais na materialidade linguística. 
Na universidade focalizada, náo existe uma forma rígida para a escrita do RES. Portanto, devido a solicitaçáo dos alunos-mestre, oferecemos instruçóes orais, de esclarecimento, em forma de roteiro, para a realizaçâo dessa escrita, tais como alguns elementos pré-textuais (capa, contracapa, entre outros elementos opcionais), textuais (introduçăo, fundamentaçăo teórica, desenvolvimento do relatório ou texto principal, consideraçóes finais), pós-textuais (referências bibliográficas, anexos com fotos, atividades didáticas, documentos legais que orientam o desenvolvimento dos estágios, fichas de estágio, dentre outros) e, seguiram as normas da ABNT. A critério dos acadêmicos, desde a introduçâo e, no corpo principal do texto, eles poderiam registrar as experiências vivenciadas e articular com as leituras da literatura especializada realizada.

Orientamos aos alunos-mestre que, na escrita do RES, apresentassem o campo de estágio; verificassem e analisassem o livro didático utilizado pelo professor-colaborador; observassem os métodos e estratégias empregados para ensinar a língua inglesa; o nível de proficiência linguística do professor-colaborador (satisfatória; insatisfatória) e dos estudantes; a formaçăo acadêmica deste profissional em exercício da profissâo; os demais recursos didáticos utilizados nas aulas; como ocorre o ensino das quatro habilidades da língua (compreensăo oral, leitura, fala, escrita); como ocorre o ensino do vocabulário e da gramática; se as aulas de língua inglesa eram planejadas; como os estudantes sâo avaliados; observassem e compreendessem a maneira como o professor-colaborador ensina e as suas condiçôes de trabalho.

Sugerimos ainda aos acadêmicos para nâo utilizar na escrita dos RES os nomes reais da escola, do educador e dos alunos envolvidos no estágio realizado para evitar a exposiçăo da instituiçáo ou das pessoas que colaboraram para a realizaçấo das atividades da disciplina. Para isso, pseudônimos foram empregados. O conjunto de orientaçôes dadas aos acadêmicos foi uma possibilidade para guiar as suas açôes em campo.

Os RES aqui investigados possuem informaçóes em comum, embora apresentam singularidades, pois foram produzidos a partir das experiências vivenciadas pelos alunos-mestre em um mesmo contexto, uma escola municipal, pertencente à cidade de lotaçăo do curso. As atividades de observaçăo de aulas aconteceram nas séries $7^{\circ}$, $8^{\circ}$ e $9^{\circ}$ ano do Ensino Fundamental II da Educaçăo de Jovens e Adultos (EJA) ${ }^{3}$, com o mesmo professor-colaborador, um docente com contrato temporário, graduado em História, mas que, no momento de geraçâo dos dados desta pesquisa, ensinava as disciplinas de Ciências e Língua Inglesa. Atualmente, o docente é responsável por ensinar as disciplinas de Matemática, Ensino Religioso e Língua Inglesa e é bastante engajado na militância religiosa, acolhedor, disposto a aprender e trocar experiências.

Nesta seçăo, reproduzimos três principais excertos em que os alunos-mestre fazem referências explícitas ao professor-colaborador, à formaçăo acadêmica e ao modo de ensinar do professor. Săo referências construídas durante as atividades de observaçáo de aulas.

3 A EJA é uma modalidade de ensino que tem como objetivo oferecer educaçáo básica a jovens e adultos que, por diversos motivos, foram excluídos do sistema educacional na idade apropriada. 
Excerto 01:

Também vamos saber alguns detalhes do professor Anésio que ministrava as aulas de inglês. Ele é graduado em história, com especializaçâo em gestâo e segurança do trânsito e gestâo pública. É bacharel em teologia e ocupa uma posiçáo de presbítero na igreja onde congrega. Um fato curioso que observei em relaçáo à crença do professor é que durante todas as aulas ele deixava sua bíblia sobre a mesa, acredito que era uma forma de professar sua fé. Ele sempre fazia um sermáo de aproximadamente de 15 minutos para começar a ministras as aulas.

Aluno-mestre 01, Estágio I, 2016.2, desenvolvimento ou corpo principal do RES

O Excerto 01 é precedido de informaçôes sobre o local do estágio; a recepçăo do aluno-mestre nas visitas à escola-campo; o patrimônio da instituiçăo; os horários de funcionamento das aulas de língua inglesa; o espaço físico e as tensōes e ansiedade do estagiário ao dar início às atividades de observaçāo de aulas. Após o Excerto 01, o aluno-mestre continua argumentando a respeito do uso que é feito do livro didático e, para isso, considera e concorda com o discurso propagado nas teorias e estudos científicos. Em seguida, discute sobre o método de ensino de língua adotado, a falta de planejamento das aulas e o modo de avaliar.

No excerto em destaque, o aluno-mestre informa a formaçáo acadêmica do professor-colaborador, responsável pela disciplina de Língua Inglesa, na escola de educaçâo básica, pertencente ao contexto focalizado (Ele é graduado em história, com especializaçâo em gestâo e segurança do trânsito e gestâo pública. É bacharel em teologia). Ao divulgar a informaçăo, certamente, o enunciador salienta que o docente năo possui qualificaçâo para atuar no ensino de língua inglesa. $\mathrm{O}$ aluno-mestre, ainda, descreve fatos ocorridos que mais lhe chamaram a atençăo durante as atividades de observaçâo de aulas, assim como revela a construçáo Um fato curioso. Apresenta argumentos que mostram as suas impressōes em relaçáo às experiências vivenciadas.

Na sequência, o aluno-mestre apresenta alguns destaques entre os acontecimentos ocorridos nas aulas analisadas (Um fato curioso que observei em relaçâo à crença do professor é que durante todas as aulas ele deixava sua bíblia sobre a mesa, acredito que era uma forma de professar sua fé. Ele sempre fazia um sermáo de aproximadamente de 15 minutos para começar a ministras as aulas). 0 uso do processo mental acredito aponta uma provável ideia do aluno-mestre e sinaliza a sua própria voz diante das açôes tidas como improprias do fazer docente. Sobre essa questăo, o informante 02 deste trabalho também afirma que:

Durante a aula, o assunto religiáo é bastante comentado, posto que, alguns alunos e o próprio professor Aristóteles săo evangélicos. O assunto toma um tempo considerável da aula e apresenta posiçōes extremamente preconceituosas, intolerante e radical por parte de alguns estudantes. O professor, no entanto, prega a tolerância, mas insiste que todos devem temer a Deus, para náo arder no fogo do inferno (Aluno-mestre 02, Estágio I, 2016.2, desenvolvimento ou corpo principal do RES).

A diversidade cultural religiosa é um direito garantido pelo cidadâo na Constituiçăo Federal (CF, 1988, artigo 210, parágrafo primeiro). Sobretudo, a sala de aula é um espaço marcado por valores e tradiçóes diversas. 0 tratamento desse assunto constitui-se tarefa árdua aos educadores, năo sendo correto impulsionar qualquer tipo de crença religiosa nesse espaço. 
Para tratar da educaçăo religiosa, a Lei de Diretrizes e Bases da Educaçăo Nacional (LDB, Lei n. ${ }^{\circ}$ 9.394, de 1996, artigo 33) e suas atualizaçôes e modificaçôes posteriores (Lei n. ${ }^{0}$ 9.475, de 1997), institucionalizaram, no espaço escolar, o Ensino Religioso de matrícula facultativa, configurando-se como componente curricular e disciplinar da formaçâo básica do cidadâo. Contudo, nâo é papel desta disciplina tratar de conversăo dos alunos. No contexto em destaque, compreendemos que o professor-colaborador, supostamente, usa-se dos artifícios religiosos até mesmo nas aulas de Língua Inglesa como um recurso transmissor de valores morais para enfrentar problemas comuns da unidade escolar, tais como indisciplina dos alunos, insegurança, violência, uso de drogas ilícita, roubos, enfatizar o respeito pelo outro e, provavelmente, até mesmo para preservar a sua autoridade 4 .

Ainda no Excerto 01, os processos fazia e começar que constituem açóes físicas (ele deixava sua bíblia sobre a mesa e Ele sempre fazia um sermâo de aproximadamente de 15 minutos) apontam que o aluno-mestre é apenas um expectador dos acontecimentos narrados, pois estava cursando o estágio de observaçáo.

Em nenhum momento, o professor-colaborador do estágio foi conduzido pelo aluno-mestre, nem mesmo por nós, professora-orientadora, a problematizar e a investigar criticamente a sua prática para produzir conhecimentos necessários para inovar e transformar as suas açóes. Além do mais, năo foram apontados caminhos que indicassem a soluçáo dos problemas identificados na labuta pedagógica. A atividade de observaçăo de aula teve, portanto, caráter avaliativo, pois foi expresso um parecer sobre o modo como o professor-colaborador trabalha. É necessário que a observaçâo de aula adquira um novo sentido, promovendo espaço para a troca de conhecimentos entre os sujeitos envolvidos no estágio.

O Excerto 02 é precedido das seguintes informaçôes: o local do estágio; a acolhida na unidade escolar; a infraestrutura da instituiçâo; a interaçâo com os profissionais e alunos que colaboraram para a realizaçâo das atividades da disciplina; a descriçâo da rotina da unidade escolar; o convite e a participaçáo do aluno-mestre em uma apresentaçăo musical em homenagem ao dia do professor, pois o mesmo é músico, cantor e compositor bastante conhecido na regiâo; a descriçăo do evento; alguns fatores que dificultam o trabalho pedagógico, a exemplo da escassez ou ausência de recursos didáticos adequados para a aprendizagem de línguas, carga horária reduzida, docente que assume a disciplina de língua inglesa fora da área de atuaçăo profissional, indisciplina dos alunos, iluminaçấo inadequada, dentre outros.

$4 \quad$ Sobre o Ensino Religioso nas escolas públicas brasileiras, conferir os trabalhos de Cavaliere (2007) e Pinho e Vargas (2015). 
Excerto 02:

Iniciada a aula, o professor informou que eles iriam rever o conteúdo aplicado na aula anterior, visto nâo terem tido tempo suficiente para debater o texto, uma carta trocada entre amigos. A estratégia adotada pelo professor foi copiar o texto no quadro e, ao lado, anotava a traduçáo de cada frase. Năo houve qualquer tipo de "warm up" antes de adentrar no conteúdo a ser estudado, o que poderia antecipadamente introduzir os alunos no universo do texto, ativando seus esquemas mentais e mapas semânticos. Outro problema que observei, refere-se à pronúncia e a forma de traduçăo. Quanto a pronúncia, percebi que o professor apresenta algumas dificuldades típicas de quem nâo tem formaçăo específica em língua inglesa. Nesse caso, o professor tem formaçăo específica em história, e atua na disciplina de inglês para complementar a carga horária que precisa ser fechada. Isso é prática recorrente e configura-se comum sério problema a ser enfrentado pela escola pública no Brasil, além de reduzir o espaço do profissional habilitado em língua estrangeira. No que diz respeito à traduçáo, segue-se o método tradicional, ou seja, traduz-se palavra por palavra, sem considerar o contexto ou a perspectiva da inferência que possibilita construir sentido e significado.

Aluno-mestre 02, Estágio I, 2016.2, desenvolvimento ou corpo principal do RES

No Excerto 02, o aluno-mestre relata e reflete a respeito da primeira aula de língua inglesa observada. Na aula, conforme informado, foi proposto o estudo de uma carta trocada entre amigos, atividade essa que havia sido iniciada em aula anterior.

As açôes docente descritas foram informadas por atividades da tradiçăo de letramento escolar, visto que as práticas desenvolvidas pelo professor-colaborador estăo a serviço unicamente do grupo escolar. O professor transcreveu a carta no quadro, em seguida, ele mesmo fez a traduçăo desse gênero de maneira automática (A estratégia adotada pelo professor foi copiar o texto no quadro e, ao lado, anotava a traduçáo de cada frase). Sobre esta questăo, em outro momento do RES, o autor do Excerto 01, reproduzido anteriormente, também comenta que: “Do início ao fim de cada aula, o professor Anésio apenas copiava e fazia a traduçâo sozinho, que segundo ele mesmo, era feita pelo Google tradutor. Os alunos apenas copiavam nada mais, năo tinham uma participaçăo ativa da turma".

Reproduzir conteúdo no quadro náo garante a compreensăo das ideias presentes no gênero estudado. Para atingir a significaçăo do mesmo, é necessário considerar também os diversos fatores linguísticos e extralinguísticos. O recurso didático utilizado para a transmissâo do conteúdo escolar năo possui qualquer ineditismo.

Ainda no Excerto 02, os processos copiar e anotava que constituem açóes físicas (A estratégia adotada pelo professor foi copiar o texto no quadro e, ao lado, anotava a traduçâo de cada frase), apontam que o aluno-mestre 02 também é um expectador dos acontecimentos narrados, durante as atividades de observaçáo de aulas.

No contexto descrito, os estudantes costumam receber as traduçóes prontas do professor. Nâo há um esforço por parte desses aprendizes para realizar esse tipo de exercício. Eles sáo solicitados a apenas copiarem do quadro a transmissăo da mensagem de um sistema linguístico para outro, sem objetivos precisos. Desse modo, esse tipo de atividade náo é utilizada como procedimento que pode ajudar no desenvolvimento linguístico e cognitivo dos estudantes (No que diz respeito à traduçấo, segue-se o método tradicional, ou seja, traduz-se palavra por palavra, sem considerar o contexto ou a perspectiva da inferência que possibilita construir sentido e significado). Portanto, o ensino de língua inglesa é feito por meio do exercício de traduçăo de palavras e frases isoladas, gerando falta de sentido e, consequentemente de comunicaçăo. 
O aluno-mestre ainda relata que năo houve na aula observada nenhum tipo de warm-up. Em adesăo às ideias presentes nas leituras realizada na disciplina de estágio no contexto acadêmico, ele acredita que utilizar warm-up é uma oportunidade de introduzir os estudantes no conteúdo a ser trabalhado e ativar os seus esquemas mentais vinculados à língua inglesa de forma mais produtiva. Essa estratégia pode culminar na produçăo de um mapa semântico, assim como mostra o uso do modalizador de probabilidade poderia (Nâo houve qualquer tipo de "warm up" antes de adentrar no conteúdo a ser estudado, o que poderia antecipadamente introduzir os alunos no universo do texto, ativando seus esquemas mentais e mapas semânticos). Textualmente, esse modalizador é uma forma do enunciador manifestar seus pontos de vista com menos comprometimento enunciativo.

Outro fato destacado pelo aluno-mestre no excerto refere-se à dificuldade do professor-colaborador no uso da pronúncia das palavras em língua inglesa de forma inteligível. Em sua percepçăo, a dificuldade em utilizar essa micro-habilidade de fala justifica-se devido ao mesmo nâo possuir formaçâo acadêmica na área que ensina, assim como sinaliza a escolha do processo mental percebi (Quanto a pronúncia, percebi que o professor apresenta algumas dificuldades típicas de quem náo tem formaçáo específica em língua inglesa). Consequentemente, os estudantes nâo săo incentivados a realizar atividades que envolvem a fala.

Conforme informado no excerto, a formaçăo acadêmica do professor-colaborador, responsável pela disciplina de Língua Inglesa, no contexto investigado é em História. Como a Língua Inglesa possuí carga horária reduzida, ou seja, cada turma possui apenas duas aulas na semana ${ }^{5}$, um docente de inglês necessita de muitas turmas para cumprir a sua carga horaria. Logo, tem sido comum a oferta dessa disciplina por profissionais de outras áreas, como um meio de complementar carga horaria de trabalho, reduzindo o campo de atuaçáo dos profissionais habilitados para ensinar o idioma.

Após o Excerto 02 exibido, o aluno-mestre anuncia que a aula por ele observada, provavelmente, năo foi planejada, pois a transcriçáo do texto no quadro e a traduçấo ocuparam todo o tempo da aula, năo restando um período para a reflexáo crítica do conteúdo proposto para o ensino. Por fim, comenta a respeito das lamentaçóes e angústias do profissional diante da falta de estímulo dos discentes.

Durante a atividade de observaçăo, o autor do Excerto 02 analisa o desempenho da prática do professor-colaborador, no entanto, năo negligencia uma análise dos porquês da prática desse profissional e o contexto sócio-histórico do seu trabalho. Dentre as dificuldades variadas para a realizaçăo do trabalho docente, certamente, a falta de qualificaçăo desse ator social na área de língua inglesa contribui para a oferta de atividades escolares com pouca atratividade para os alunos.

O Excerto 03, reproduzido adiante, de autoria de uma aluna-mestra, é precedido das seguintes informaçôes: descriçăo sobre as aulas teóricas de estágio que aconteceram

5 É importante destacar que, com a reformulaçâo da Estrutura Curricular das escolas estaduais do Tocantins, a partir do primeiro semestre de 2017, a carga horaria da disciplina de Língua Inglesa foi reduzida. Houve a reduçáo de uma aula no $9^{\circ}$ ano do Ensino Fundamental II e uma aula em cada série do Ensino Médio. As aulas reduzidas foram transferidas para os primeiros anos do Ensino Fundamental I e serâo ministradas pelos regentes de sala, em sua maioria, os regentes sâo pedagogos sem formaçâo em Língua Inglesa. 
no contexto acadêmico; apresentaçăo da escola-campo de estágio; informaçôes sobre as turmas selecionadas para observaçâo de aulas; período de realizaçâo das atividades práticas da disciplina; infraestrutura da unidade concedente; ansiedade e expectativa para iniciar a observaçăo de aulas. A autora do documento ainda ressalta que a manifestaçâo do cristianismo é percebida através de textos com mensagens encorajantes e versículos bíblicos gravados em forro de mesa, nos murais e em cartazes nas paredes da instituiçâo.

\section{Excerto 03:}

[...] A formaçăo do professor-colaborador é em História com especializaçăo em Teologia, mas ele trabalha no Detran da cidade onde atua como especialista em trânsito. [...].

Enfim chegou o tăo esperado dia de começar o meu trabalho! No horário marcado eu estava lá para fazer a minha observaçáo. No primeiro dia acompanhei uma aula na turma do $7^{\circ}$ ano e desde o princípio pude perceber que muita coisa náo estava funcionando como deveria por ali e assim se seguiu em todas as turmas. Apesar de todas as salas serem amplas, arejadas, muita coisa deixava a desejar quanto à maneira como as coisas eram conduzidas ali. O que mais me chamou atençấ, além da falta de planejamento foi o fato de o professor levar quase metade da aula que tem uma duraçáo de apenas 45 minutos fazendo leituras de versículos bíblicos. Náo estou aqui querendo dizer que náo se deve falar de Deus nas escolas, nada disso, apenas acho que o tempo utilizado para esse fim é que foi longo o que faz com que a aula fique ainda mais curta.

No decorrer das aulas foi que veio a minha maior preocupaçăo: eu estava diante de uma pessoa que ao meu ver, compreende menos da língua que ensina do que eu sendo ainda uma estudante estagiária. Comecei entâo a ficar inquieta com aquela situaçáo. Ficava imaginando o que eu iria aprender com ele. As coisas năo andavam para frente, năo era o que eu desejava encontrar. O que eu pude observar foi que em todas as salas o método de ensino utilizado pelo professor era sempre o mesmo - o método da gramática e da traduçâo que é o método que consiste basicamente no ensino da segunda língua pela primeira (Leffa, 1998).

Aluna-mestra 03, Estágio I, 2016.2, desenvolvimento ou corpo principal do RES

Logo no início do Excerto 03, a aluna-mestra informa a formaçăo acadêmica do professor-colaborador, responsável por ensinar a disciplina de Língua Inglesa, na escola-campo de estágio. Assim como os demais alunos-mestre, ao divulgar essa informaçăo, a enunciadora sugere que o docente năo possui qualificaçăo para atuar na área de língua inglesa. No excerto, a construçâo argumentativa mas ele trabalha no Detran da cidade onde atua como especialista em trânsito inclui uma relaçâo de acréscimo por características adversativas (mas), em que é indicado uma nova informaçăo, ou seja, além da docência, o professor-colaborador é servidor público no Departamento Estadual de Trânsito do Tocantins, o Detran/TO. Portanto, a docência é um trabalho adicional para complementar a renda, "um bico", apropriando-nos dos próprios termos utilizado pela acadêmica em seu relatório. Apesar de ser servidor do Detran, atualmente, o docente, está lotado na Casa de Prisâo Provisória do município e exerce a funçâo de capelâo eclesiasticístico.

Em seguida, a aluna-mestra descreve a primeira aula de língua inglesa observada, em uma turma de $7^{\circ}$ ano, momento esse aguardado com muita expectativa, o que é apontado pelo intensificador tâo (Enfím chegou o tâo esperado dia de começar o meu trabalho!). E assim, inscreve-se no discurso ao expressar sua persepçăo dos fatos vivenciados, sinalizado no uso do processo mental perceptivo perceber (desde o princípio pude perceber que muita coisa náo estava funcionando como deveria por ali), apontando atitude de desaprovaçăo em relaçăo à açôes desenvolvidas pelo docente que năo estavam sendo cumpridas como se desejava. 
No excerto, a construçáo apesar de (Apesar de todas as salas serem amplas, arejadas, muita coisa deixava a desejar quanto à maneira como as coisas eram conduzidas ali) expressa uma ideia contrária em relaçâo as açôes desempenhadas pelo docente e, ainda, oferece informaçôes adicionais acerca da estrutura das salas de aula.

Na sequência, a aluna-mestra destaca episódios vivenciados que considerou marcantes, como a falta de planejamento de aulas e, sem entrar na discussâo e nas controvérsias existentes, ressaltou o período longo do tempo utilizado na aula para a realizaçăo de leitura de versículos bíblicos ([...] o fato de o professor levar quase metade da aula que tem uma duraçáo de apenas 45 minutos fazendo leituras de versículos bíblicos). Essa situaçăo, também foi destacada pelos alunos-mestre 01 e 02, conforme já chamamos a atençăo.

As construçôes verbal dizer e mental cognitivo acho (Nâo estou aqui querendo dizer que náo se deve falar de Deus nas escolas, nada disso, apenas acho que o tempo utilizado para esse fim é que foi longo o que faz com que a aula fique ainda mais curta), inscrevem a aluna-mestre em seu próprio discurso e indicam seus pontos de vista.

No excerto, a aluna-mestre impressiona-se com o nível insatisfatório de proficiência linguística do professor-colaborador na língua inglesa (No decorrer das aulas foi que veio a minha maior preocupaçáo: eu estava diante de uma pessoa que ao meu ver, compreende menos da língua que ensina do que eu sendo ainda uma estudante estagiária). A situaçấo relatada causou-lhe desassossego, pois a informante acreditava que iria observar aulas que poderiam ser modelos a serem seguidos por ela. Contudo, é necessário compreender que, nas atividades práticas do estágio supervisionado, nem sempre será possível encontrar modelos de aulas a serem seguidas. A investigaçâo científica pode auxiliar a aluna-mestra a realizar uma leitura crítica do contexto vivenciado, posicionar-se diante dos fatos e oferecer alternativas em reposta às demandas específicas do local de trabalho pedagógico.

Por fim, a aluna-mestra trata da questăo do método de ensino de língua inglesa utilizado nas aulas observadas, que de acordo com ela é o da gramática e da traduçâo. Para esclarecer a proposta desse método, filia-se ao discurso acadêmico para sustentar suas discussóes ao utilizar uma citaçăo indireta da literatura especializada estudada nas aulas teóricas da disciplina ( $O$ que eu pude observar foi que em todas as salas o método de ensino utilizado pelo professor era sempre o mesmo - o método da gramática e da traduçâo - que é o método que consiste basicamente no ensino da segunda língua pela primeira (Leffa, 1998)). O uso dos parênteses com o nome do autor e ano da publicaçáo do discurso enunciado indica a origem da voz alheia incorporada no excerto. Para introduzir o discurso indireto, que é um tipo de enunciado que representa o dizer/pensamento do outro por reformulaçấo, a aluna-mestra nâo utiliza comentário nem especificaçâo intencional que reconhece o empréstimo de remissáo à voz alheia, havendo assim, uma harmonia reforçada entre voz própria e discurso citado.

Diante dos dados de pesquisa aqui analisados, compreendemos que os relatórios de estágio foram escritos pelos alunos-mestre em resposta às orientaçôes fornecidas na disciplina. Em síntese, esses acadêmicos apresentam o campo de estágio, a organizaçâo das aulas observadas, destacam episódios que consideram marcantes, associam o que leram às experiências vividas nas atividades práticas da disciplina.

No entanto, a observaçâo de aulas consistiu em uma funçăo avaliativa de como o 
professor-colaborador desempenha a sua prática. Os alunos-mestre, no papel de observadores, olham para a aula do outro para analisar a sua qualidade, apontar aspectos concebidos como positivos ou negativos. Na perspectiva dos pressupostos teóricos assumidos neste artigo, acreditamos que a observaçăo de aulas pode adquirir um novo sentido, tornando-se um espaço para cultivar e compartilhar saberes entre aluno-mestre, professor-colaborador e professora-orientadora. É necessário que essa atividade deixe de ser vista com a funçâo de fazer apenas avaliaçóes da prática do professor em exercício da profissăo e, passe a caracterizar-se como atividade coparticipativa, desencadeando a compreensâo das práticas pedagógicas observadas (BIAZI; GIMENEZ; STUTZ, 2011), além de possibilitar a intervençăo em sala de aula como resposta aos problemas pedagógicos identificados e analisados.

\section{CONSIDERAÇÕES FINAIS}

A citaçăo de Freire transcrita na introduçăo deste artigo chama a nossa atençâo para a importância de que a indagaçăo, a busca e a pesquisa devem fazer parte da natureza da prática docente. Tanto a professora-formadora como o professor-colaborador e os alunos-mestre aprendem quando pesquisam. Ao ensinar aprende-se o conhecimento já existente, ao pesquisar produz-se o conhecimento ainda năo existente. Portanto, educar através da pesquisa náo é apenas transmitir conteúdos, mas sim ensinar a aprender. É criar possibilidades para o aluno desenvolver a sua autonomia.

Neste trabalho, năo tivemos como propósito detectar problemas e apontar culpados ao trabalho pedagógico na escola-campo de estágio, mas sim contribuir com a realidade escolar identificada, possibilitando o ensino para formaçăo autônoma dos alunos da educaçăo básica. Apesar de nâo termos propiciado condiçôes imediatas para a transformaçâo no modo de ensinar a língua inglesa em sala de aula que beneficiassem a escola de algum modo, conversamos com os gestores da escola e o secretário de educaçấo do município sobre a importância de o professor-colaborador assumir disciplinas em sua área de formaçáo acadêmica. Os resultados desta pesquisa foram compartilhados com o professor-colaborador, o qual teve acesso ao texto integral do artigo.

Convidamos o professor-colaborar do estágio para realizar a sua matrícula no curso de Língua Inglesa no Centro de Estudos Continuados em Letras, Linguística e Artes (CECLLA) ${ }^{6}$ na universidade focalizada neste artigo. O professor realizou o curso no nível básico I, ministrado por um dos alunos-mestre, informante desta pesquisa. Em encontros informais que tivemos com o professor, ele ressaltou que o curso tem lhe propiciado alternativas para tentar inovar as suas aulas na educaçăo básica. No entanto, ainda precisamos criar dispositivos diferenciados para contribuir com a ressignificaçâo e o aperfeiçoamento das competências desse profissional, atendendo às demandas imediatas da sala de aula.

$6 \quad$ O CECLLA é um centro de idioma que oferece curso de línguas gratuito à comunidade interna e externa. O curso é ministrado por acadêmicos da própria licenciatura em Letras da UFT, Porto Nacional, ao longo de, aproximadamente, três meses cada nível. As atividades dos acadêmicos sáo supervisionadas por um professor-formador da licenciatura em Letras/Inglês, o qual oferece suporte por meio de orientaçōes teórico-práticas. 


\section{REFERÊNCIAS}

BAKHTIN, M. (VOLOCHINOV). Marxismo e filosofia da linguagem. Traduçáo Michel Lahud e Yara Frateschi Vieira. 10. ed. Sáo Paulo, Editora HUCITEC, 2002.

BAKHTIN, M. Estética da criaçăo verbal. Traduçâo Maria Ermentina Galvâo. 3. ed. Sáo Paulo, Martins Fontes, 2000.

BAKHTIN, M. Problemas da poética de Dostoiévski. Traduçăo Paulo Bezerra. 5. ed. Rio de Janeiro: Forense Universitária, 2013.

BIAZI, T. M. D.; GIMENEZ, T.; STUTZ, L. O papel da observaçâo de aulas durante o Estágio Supervisionado de Inglês. SIGNUM: Estudos da Linguagem, Londrina, n. 14/1, jun. 2011. p. 57-78.

BRAIT, B.; PISTORI, M. H. C. A produtividade do conceito de gênero em Bakhtin e o círculo. ALFA: Revista de Linguística, Săo Paulo, 56 (2), 2012. p. 371-401.

CAVALIERE, A. M. O mal-estar do ensino religioso nas escolas públicas. Cadernos de Pesquisa, v. 37, n. 131, maio/ago. 2007. p. 303-332.

CELANI, M. A. A. A relevância da linguística aplicada na formaçáo de uma política educacional brasileira. In: FORTKAMP, M. B. M.; TOMITCH, L. M. B. (Org.). Aspectos da linguística aplicada: estudos em homenagem ao professor Hilário Inácio Bohn. 2. ed. Florianópolis: Insular, 2008. p. 17-32.

DEMO, P. Educaçâo e alfabetizaçāo científica. Campinas: Papirus, 2010.

FIAD, R. S.; SILVA, L. L. M. da. Escrita na formaçáo docente: relatos de estágio. Revista Acta Scientiarum. Language and Culture. Maringá:EDUEM, v. 31, n. 2, 2009. p. 123-131.

FREIRE, Paulo. Pedagogia da autonomia: saberes necessários à prática educativa. Sâo Paulo: Paz e Terra, 1999.

MATEUS, E. Torres de babel e línguas de fogo: um pouco sobre pesquisa na formaçáo de professores de inglês. In: Revista Brasileira de Linguística Aplicada, v.9, n.1, 2009. p. 307-328.

MELO, L. C. Abordagem interdisciplinar de trabalho pedagógico com histórias em quadrinhos: uma proposta orientada pelo letramento científico. 2017. (texto no prelo).

PIMENTA, S. G.; LIMA, M. S. L. Estágio e docência. Săo Paulo: Cortez, 2004.

PINHO, L. G.; VARGAS, E. F. M. Ensino Religioso no Estado do Rio de Janeiro: conceitos, história e legislaçôes. Educ. temat. digit. Campinas, SP v.17 n. 2, maio/ago. 2015. p. 308-327.

SÁ-SILVA, R;ALMEIDA, C. D. de.; GUINDANI, J. F. Pesquisa documental: pistas teóricas e metodológicas. Revista Brasileira de História \& Ciências Sociais. Ano I. n. I. Julho de 2009. p. 1-15.

SASSERON, L. H.; CARVALHO, A. M. P. Almejando a alfabetizaçăo científica no Ensino Fundamental: a proposiçăo e a procura de indicadores do processo. In: Investigaçōes em Ensino de Ciências - v.13 (3), 2008. p. 333-352.

SILVA, W. R. Letramento Científico na formaçăo inicial do professor. Revista Práticas de Linguagem, v. 6 especial - Escrita discente, 2016. p. 8-23.

Recebido em novembro de 2017.

Aceite em fevereiro de 2018. 